\title{
ФОРМУВАННЯ МОТИВАЦІЇ ДО НАВЧАЛЬНО-ПІЗНАВАЛЬНОЇ ДІЯЛЬНОСТІ МАЙБУТНІХ УЧИТЕЛІВ У ПРОЦЕСІ ІНСТРУМЕНТАЛЬНО-ВИКОНАВСЬКОЇ ПІДГОТОВКИ В УМОВАХ МОДУЛЬНО-РЕЙТИНГОВОГО НАВЧАННЯ
}

Глазунова I. К. Формування мотивації до навчально-пізнавальної діяльності майбутніх учителів у процесі інструментально-виконавської підготовки в умовах модульно-рейтингового навчання.

У статті представлено результати експериментального дослідження методів формування мотивації до навчально-пізнавальної діяльності майбутніх учителів в процесі інструментально-виконавської підготовки в умовах модульно-рейтингового навчання. Розглянуто поняття «модуль» як основи модульно-рейтингової організації навчального процесу та модульний підхід як один із видів особистісно-орієнтованого підходу в процесі навчання мистецтва. 3'ясовано, що активізація мотиваційної сфери студента для досягнення успішності в інструментально-виконавській діяльності відбувається завдяки пристосуванню можливостей модульно-рейтингового навчання до потреб, нахилів, рівня музично-виконавського розвитку кожного студента.

Ключові слова: інструментально-виконавська підготовка, методи активізації мотиваційної сфери студентів, модульно-рейтингове навчання.

Глазунова И. К. Формирование мотивации к учебно-познавательной деятельности будущих учителей в процессе инструментально-исполнительской подготовки в условиях модульно-рейтингового обучения.

В статье представлены результаты экспериментального исследования методов формирования мотивации к учебно-познавательной деятельности будущих учителей в процессе инструментально-исполнительской подготовки в условиях модульнорейтингового обучения. Рассмотрено понятие «модуль» как основы модульнорейтинговой организации учебного процесса и модульный подход как один из видов личностно-ориентированного подхода в процессе обучения искусству. Выяснено, что активизация мотивационной сферы студента для достижения успешности в инструментально-исполнительской деятельности происходит благодаря приспособлению возможностей модульно-рейтингового обучения к потребностям, наклонностям, уровню музикально-исполнительского развития каждого студента.

Ключевые слова: инструментально-исполнительская подготовка, методы активизации мотивационной сферы студента, модульно-рейтинговое обучение.

Glazunova I. K. Forming of motivation to educational-cognitive to activity of future teachers in the process of instrumental-carrying out preparation in terms of module-rating educating.

In the article the results of experimental research of motivation forming methods to educational-cognitive activity of future teachers in the process of instrumental-carrying out preparation in the conditions of the module-rating educating are presented. A concept of «module» is considered as bases of module-rating organization of educational process and module approach as one of types of the personality oriented approach in the process of educating art.

Key words: instrumental-carrying out preparation, methods of activation of 
motivational sphere of student, module-rating educating.

На сучасному етапі розвитку педагогічної науки зростає роль нових підходів до вдосконалення якості освіти. Приєднання України до Болонської системи вимагає переосмислення та розробки сучасних організаційних і методичних засад підготовки вчителів з урахуванням загальних критеріїв і стандартів європейського освітнього простору. Необхідною умовою приєднання до єдиного європейського освітнього співтовариства $\epsilon$ використання кредитно-модульної системи організації навчального процесу.

Кредитно-модульну систему в Україні розглядають не тільки як основу для всіх ступенів вищої освіти, але і як нову технологію організації навчального процесу, спрямовану на підвищення якості вищої освіти. Отже, головною метою процесу навчання у вищій школі $€$ постійне підвищення якості підготовки майбутніх фахівців [1].

Однак швидкий перехід від сучасної системи організації навчального процесу до нової системи неможливий, тому освітній процес збагачується педагогічними технологіями, близькими за своєю суттю до кінцевої мети Болонського процесу, але набагато більш гнучкими на перехідному, адаптаційному етапі [2].

Такою системою навчання $\epsilon$ модульно-рейтингова організація навчального процесу, яка $є$ одним $з$ видів особистісно орієнтованого підходу. Під цим поняттям розуміється тип навчання, за якого «організація взаємодії суб'єктів навчального процесу максимальною мірою спрямована на індивідуальні особливості (цінності, установки, інтелект, здібності тощо) і специфіку особистісного моделювання світу» [2, с. 71]. Практична реалізація ідей особистісно орієнтованого навчання передбачає зміну підходів до оцінки його ефективності, яка повинна повноцінно відображати динаміку розвитку особистості, самореалізацію іiі пізнавальних можливостей, підвищення якості навчання [3]. У загальнонауковому сенсі під поняттям «ефективність» розуміється дієвий процес, що сприяє досягненню потрібного ефекту, що оптимальних результатів навчальної діяльності [3].

Модульний підхід у навчанні відрізняється від традиційного цілями, завданнями, програмно-методичним забезпеченням, структуруванням змісту, забезпеченням активними методами навчання та формами організації і тощо. Питання упровадження модульно-рейтингового навчання в різних аспектах висвітлюються в дослідженнях таких науковців: Дж. Гарфілда, С. Постлесуайта, Дж. Рассела, Р. Херста, Дж. Шнайдера, П. Юцявичене та ін. В Україні проблеми модульного навчання вивчали А. Алексюк, В. Бондар, Р. Вернидуб, М. Згуровський, П. Сікорський, О. Сидорко, М. Сукнова, Н. Шиян, О. Ярошенко та ін.

Сутність модульної організації навчального процесу полягає в тому, «що модуль $\epsilon$ цільовим функціональним вузлом, в якому об'єднано: зміст навчання і технологію оволодіння його в систему високого рівня цілісності» [2, с. 45].

Саме модуль може бути навчальною програмою, індивідуалізованої за змістом, методами навчання, рівня самостійності студентів, темпом навчально-пізнавальної діяльності [1]. У цих сутнісних характеристиках закладено відміну модульного навчання від інших систем навчання. Необхідно зазначити, що проблема інструментальновиконавської підготовки майбутніх учителів музики на основі використання модульнорейтингової системи навчання характерна як для вітчизняних, так і закордонних музичних факультетів педагогічних ВНЗ. Можливості її використання досить повно розкриваються в індивідуальному навчанні, до якого належить інструментально-виконавська підготовка майбутніх учителів музики. 
Активізація мотивації студентів на успішну інструментально-виконавську підготовку $\epsilon$ запорукою їх подальшої успішної фахової діяльності [3].

У науковій літературі останніх років висвітлюються різні аспекти підготовки майбутнього вчителя музики: культурологічний (Г. Падалка, О. Рудницька, О. Щолокова, О. Єременко, А. Козир, Л. Кондрацька, Т. Танько). Розкриття сутності історико-педагогічного процесу в галузі музичної освіти (Н. Гуральник, В. Черкасов). Роботи, які досліджують окремі напрями фортепіанного навчання майбутніх учителів музики: формування художнього мислення (Н. Мозгальова, О. Бурська). професійної компетентності (М. Михаськова, Ши Дзюнь-бо).

Аналіз цих досліджень показує, що проблему сформованості мотиваційної сфери майбутнього вчителя музики до навчальної та виконавської діяльності в умовах модульно-рейтингового навчання в даний час вивчено недостатньо. Виявлення особливостей інструментально-виконавської підготовки студентів в умовах модульнорейтингової системи навчання та можливостей впливу означеної організації навчального процесу на формування мотивації студентів на успішну інструментально-виконавську діяльність уважаємо важливими й актуальними.

Мета статmі полягає у виборі необхідних методів активізації мотивації щодо навчально-пізнавальної діяльності студентів у процесі інструментально-виконавської підготовки в умовах модульно-рейтингового навчання.

Для визначення цих методів нами було проведено відповідне діагностування. Зазначимо, що модульно-рейтингова система навчання спрямована на підвищення якості навчання студентів, активізації мотивації до навчально-пізнавальної діяльності та підвищення ролі самостійної роботи як важливого складника формування фахово необхідних знань, умінь і навичок майбутнього фахівця [4]. Тому перевірка методів активізації мотивації студентів до навчання в інструментальному класі базувалася на виявленні впливу означеної організації навчального процесу на формування якісного рівня професійних знань, умінь і навичок у класі інструментальної підготовки.

3 метою діагностування стану сформованості мотивації студентів було розроблено критерії та показники ефективності інструментальної підготовки. До першого критерію ми віднесли міру особистісної цілеспрямованості майбутніх учителів музики на успішну інструментально-виконавську діяльність. За означеним критерієм здійснювалась перевірка стану сформованості мотиваційної сфери студентів, наявність спонукальних мотивів навчальної та виконавської діяльності. Показниками цього критерію виступають: розвиненість потреби в музичновиконавській діяльності; вияв інтересу майбутніх учителів музики до прослуховування і виконання інструментальних музичних творів.

На основі визначених критеріїв та показників було проведено констатувальний експеримент, під час якого відбувався кількісний та якісний аналіз навчальної діяльності майбутніх фахівців. Відповідно респонденти були розподілені на чотири рівні: низький, середній, достатній $i$ високий. $\mathrm{У}$ результаті застосування діагностувальних методів (тест-опитувальник А. Реана для дослідження рівня сформованості професійної мотивації, методика К. Замфір для дослідження внутрішніх та зовнішніх мотивів діяльності) було з'ясовано, що значна кількість респондентів (79,4 \%) мають середній та низький рівні сформованості мотивації та наявність спонукальних мотивів щодо навчально-виконавської діяльності, це й дало підстави для проведення подальшої експериментальної роботи.

Перший показник сформованості мотиваційно-орієнтаційного компоненту за критерієм «Міра особистісної цілеспрямованості майбутніх учителів музики на успішну інструментально-виконавську діяльність»- розвиненість потреби в музично- 
виконавській діяльності - передбачав педагогічне стимулювання щодо отримання мистецько-виконавчих, музично-теоретичних, музично-педагогічних знань і умінь.

На адаптаційному етапі формувального експерименту для означеного педагогічного стимулювання в теоретичному блоці першого навчального модуля нами було використано спеціально розроблений «Тест на визначення інтересу студентів до інструментально-виконавської діяльності» (на основі методики О. Гребенюка). Запропоновані завдання стали стимулом усвідомлення майбутніми вчителями певного дефіциту інформації щодо мистецько-виконавчих, музичнотеоретичних і музично-педагогічних знань.

3 метою створення позитивного емоційного супроводження, клімату взаємної довіри під час проведення теоретичного блоку першого навчального модуля, для контролю результатів виконання означених завдань нами було застосовано методи самоконтролю і самооцінювання. Після виконання завдань студенти отримали «ключі», за допомогою яких ними було здійснено контроль i самооцінювання студентів.

Отже, запровадження методу самоконтролю, з одного боку, продемонструвало студентам реально існуючий у них якісний рівень мистецько-виконавчих, музичнотеоретичних, музично-педагогічних знань і дозволило усвідомити дефіцит відповідної інформації. Усвідомлення дефіциту даної інформації стало педагогічним стимулом щодо отримання студентами вище зазначених знань. 3 іншого боку, залучення методів самоконтролю і самооцінювання дозволило уникнути під час проведення модулю атмосфери хвилювання i невпевненості, що позитивно відбилося на формуванні мотиваційно-орієнтаційного компоненту інструментально-виконавської підготовленості студентів.

Важливим чинником формування мотиваційно-орієнтаційного компоненту ми вважаємо також розширення кола художнньо-естетичних потреб студентів Інститутів мистецтв. 3 метою розширення кола художнньо-естетичних потреб на індивідуальних заняттях 3 основного музичного інструменту нами було використано поєднання методів демонстрації інструментальних творів, художньої ілюстрації словесних пояснень, художнього вправляння, інтерпретаційних методів із прийомами самостійного вибору твору, самостійного оцінювання форми, засобів музичної виразності, його інструментально-педагогічного потенціалу тощо.

Оскільки проведення практичного блоку навчального модуля активізує мотиваційно-емоційне ставлення майбутніх учителів музики до ефективної реалізації власних інструментально-виконавських знань, умінь і навичок, то першочерговим завданням викладача $\epsilon$ концентрація студентів на більш емоційно привабливих моментах їх виступу. Обговорюючи у процесі підготовки навчального модулю, а також результатів його проведення найбільш вдалі елементи, викладач педагогічно пролонгував ситуацію успіху, що відповідно емоційно стимулювало художньоестетичну потребу студентів. Адже $є$ цілком закономірним їх бажання якомога частіше переживати позитивні моменти процесу інструментально-виконавської підготовки в умовах розширення власного мистецько-виконавського досвіду.

3 метою подальшого надання стимулу щодо пізнавально-виконавської діяльності тонічного характеру ми здійснювали роботу на основі використання методу оприлюднення результатів інструментально-виконавської діяльності. Зміст цього методу полягав не просто в педагогічному оцінюванні й обговоренні результатів проведення практичної частини навчального модулю, а в публічному їх оприлюдненні на полілогічній основі. Саме публічне визнання успіхів студента відігравало позитивну роль у процесі педагогічної пролонгації художньо-естетичних потреб щодо 
інструментально-виконавської діяльності, успішно адаптуючи студентів до системи модульно-рейтингового навчання [3].

Ефективним стимулом розвитку художньо-естетичних потреб студентів було залучення методу рейтингового контролю як основи для оцінювання різних сторін інструментально-виконавської підготовленості студентів. Як інструментарій для використання зазначеного методу нами було спеціально розроблено і упроваджено «Бланк рейтингової оцінки навчальних досягнень студента». Бланк містив, окрім балів за якість виконання програми навчального модуля і творчого завдання, також бали за участь у концертно-просвітницькій діяльності, у роботі НТТСМ, а також за особистісні творчі здобутки у музичних конкурсах і фестивалях.

Отже, «Бланк рейтингової оцінки навчальних досягнень студента» спонукав подальшу пролонгацію художньо-естетичних потреб майбутніх учителів, залучаючи їх до певного перевиконання навчальної програми, розширюючи іï межі у царині наукових та концертновиконавських здобутків.

Другий показник сформованості мотиваційно-орієнтаційного компоненту інструментально-виконавської підготовленості- вияв інтересу майбутніх учителів музики до прослуховування і виконання інструментальних музичних творів - сприяв створенню психологічної установки на здобуття художньо-виконавських, мистецтвознавчих, музично-історичних, музично-педагогічних та ін. знань і умінь шляхом створення у респондентів позитивного емоційного супроводження до процесу фахової підготовки в цілому й інструментально-виконавської підготовки, зокрема. Саме інтерес до прослуховування і виконання інструментальних музичних творів є основою для утворення психологічного вектору спрямованості особистості майбутнього вчителя музики на інструментально-виконавську діяльність [5].

Задля формування інтересу студентів до прослуховування i виконання інструментальних музичних творів під час підготовки і проведення навчальних модулів було здійснено варіативне застосування методів стимулювання інтересу (з групи стимулювання мотивації мистецького навчання), комплексу вербальних методів, поєднаних із методами демонстрації музичних творів, художньої ілюстрації, художнього вправляння тощо.

Метод інсценізації інструментальних творів навчальної дисципліни «Основний музичний інструмент» був використаний у процесі інструментально-виконавської підготовки згідно 3 організаційно-підготовчим напрямом реалізації модульнорейтингової системи навчання під час індивідуальних та групових занять. Зміст означеного методу полягав у сценічному втіленні студентами ідейно-художнього змісту музичного твору.

Доцільно зазначити, що застосування методу інсценізації можливе виключно у комплексі із методом демонстрації музичних творів, що утворювало бінарний метод мистецького навчання. Означений бінарний метод вельми ефективно забезпечував розвиток зацікавленості майбутніх учителів музики щодо визначення відповідних жанрово-стильових ознак інструментальних творів. Ефективною під час реалізації даного методу виявилась творча співпраця студентів-музикантів із студентамихореографами, які на фаховому рівні за допомогою хореографічних засобів здійснювали інсценізацію опрацьовуваних інструментальних творів.

Для розвитку інтересу майбутніх учителів музики до прослуховування i виконання інструментальних творів у процесі підготовки до проведення навчальних модулів нами залучався також метод навчальних дискусій. Слід зауважити, що розглядуваний метод слід використовувати лише під час групових занять. Отже, педагогічний вплив означеного методу реалізувався виключно на базі практичної 
інтеграції навчальних дисциплін. Теми для навчальних дискусій обиралися нами відповідно до змістового наповнення модуля згідно 3 інтегрованою дидактичною метою і цільовим планом.

Наприклад, інтегрована дидактична мета навчального модуля з курсу «Основний музичний інструмент» на адаптаційному етапі формування інструментальновиконавської підготовленості становила: опанування різними видами музичної фактури. Відповідно до мети для дискусій було узгоджено такі теми: «Розвиток фактури клавірної сюїти Західної Європи епохи «бароко»: поліфонічний чи гомофонно-гармонічний напрямок?»(семінарські заняття 3 навчальної дисципліни «ІІсторія зарубіжної музики»); «Методи удосконалення технічних умінь щодо точного виконання «подвійних нот» у фактурі концертів для струнних інструментів доби романтизму» (практичні заняття 3 «Оркестрового класу»); «Методичні рекомендації Г. Нейгауза щодо мистецького опрацювання різних видів фортепіанної фактури у процесі інструментально-виконавської підготовки піаніста» (За книгою Г. Нейгауза «Мистецтво фортепіанної гри») (секційне засідання НТТСМ).

Формуванню інтересу студентів до інструментально-виконавської діяльності сприяв також метод самоорганізації на адаптаційному етапі модульно-рейтингової системи навчання, який полягав у доборі навчально-педагогічного репертуару, що відповідав індивідуальному музично-виконавському рівню розвитку студента 3 урахуванням рекомендацій викладача щодо організації мистецького опрацювання визначеного репертуару. Вельми позитивним для розвитку інтересу стало поєднання означеного методу із педагогічним прийомом створення на індивідуальному занятті 3 «Основного музичного інструменту» або «Додаткового музичного інструменту» ситуації самостійного вибору музичних творів.

Пропонуючи студентові певне коло музичних творів різних жанрів, викладач надавав можливість майбутньому вчителеві музики самостійно приймати рішення щодо змісту його подальшої інструментально-виконавської діяльності згідно 3 особистим музичним смаком i стильовими уподобаннями тощо. Самостійне прийняття рішення стимулювало емоційно-вольовий чинник мотиваційної сфери студента, відповідно впливаючи на його інтерес до процесу інструментальновиконавської підготовки.

Безпосередній педагогічний вплив на сферу мистецько-виконавських інтересів студента здійснював метод демонстрації музичних творів. Даний метод був найбільш дієвим під час як індивідуальних, так і групових занять 3 циклу професійнопредметної підготовки. На нашу думку, саме бездоганна, яскрава i артистична демонстрація викладачем музичного твору, що опрацьовував студент, був одним із найважливіших чинників впливу на зацікавленність майбутніми вчителями музики в успішному результаті інструментально-виконавської діяльності. Активізація мотивації в цьому випадку підсилювалася комунікативним аспектом мистецького діалогічного спілкування викладача і студента, створюючи позитивну атмосферу на занятті, яка була важлива на адаптаційному етапі підготовки.

Метод висунення навчальних вимог, що включав поточний (під час індивідуальних занять), проміжний (під час групових занять), підсумковий (під час проведення навчальних модулів), заохочувально-узагальнюючий (під час концертних виступів) види контролю, а також рейтинговий контроль, який містив відповідно до розробленого нами «Бланку рейтингової оцінки навчальних досягнень студента» комплекс балів щодо оцінювання різних видів навчально-пізнавальної і творчовиконавської діяльності, стимулював зацікавленість студентів не тільки до якісного виконання програмних вимог, що передбачені змістом навчальних модулів, а і до 
участі у просвітницькій, науковій діяльності, до перемог на музичних конкурсах i фестивалях тощо.

Задля вимірювання другого показника сформованості мотиваційноорієнтаційного компоненту інструментально-виконавської підготовленості студентів Інститутів мистецтв ми запропонували студентам самостійно підготувати реферативні доповіді, що присвячені вирішенню проблем з питань фортепіанного виконавства (для отримання додаткових рейтингових балів). Зазначимо, що більшість студентів відгукнулися на таку пропозицію (з 72 респондентів 52 написали реферати). Проведення контрольного зрізу засвідчило позитивну тенденцію щодо якісної зміни визначеного показника.

3 огляду на вище зазначене упроваджений комплекс методів мотивації мистецького навчання, вербальних, художньо-творчих методів, методів навчання відповідно до характеру мистецької діяльності тощо забезпечив створення вектору особистісної цілеспрямованості майбутніх учителів музики на успішну інструментально-виконавську діяльність на основі відповідної психологічної установки.

3 метою виявлення рівнів сформованості мотиваційно-орієнтаційного компоненту було проведено контрольні зрізи, які продемонстрували якісні позитивні зміни показників в експериментальних групах.

Аналіз статистичних даних засвідчив, що кількість студентів з низьким рівнем сформованості інструментально-виконавської підготовленості на формувальному етапі експериментальної роботи знизилась 3 36,3\% до $29,2 \%$ (на7,1 \%) в експериментальних групах. У той час, як у контрольних групах зменшення відбувалось усього лише на 1,3\%. Зменшення кількості респондентів (на 16,6 \%) спостерігалося також на середньому рівні сформованості досліджуваного феномену. У той час, як у контрольних групах різниця склала $3.1 \%$.

Тенденція упевненого зростання відбувалася на достатньому і високому рівнях сформованості інструментально-виконавської підготовленості студентів педагогічних університетів. Так, достатній рівень демонструє зростання на $8,4 \%$ в експериментальних групах (з 13,8 \% до 22,2 \%). У той час, як зростання у контрольних групах становило лише 2,9\%. Переконливим, на нашу думку, є якісне зростання на високому рівні в експериментальних групах, яке становить 15,3 \% (3 5,5 \% до 20,8 \%) У той час, як динаміка сформованості досліджуваного феномена в контрольних групах склала лише $1,5 \%$.

Позитивні зрушення були досягнути завдяки доцільному конструюванню навчальних модулів, упровадженню у процес інструментально-виконавської підготовки вчителів музики адаптивно-варіативного підходу, який забезпечував реалізацію основних положень модульно-рейтингового навчання відповідно до специфіки навчально-пізнавальної та творчо-виконавської діяльності студентів, а також сприяв максимальній індивідуалізації пропонованої підготовки на основі можливості варіативного використання педагогічних підходів, умов, форм, методів, прийомів та засобів роботи у класі інструментально-виконавської підготовки. Комплексна експериментальна методика включала такі методи, як: проективні, конструктивні, методи стимулювання й активізації мотивації щодо навчальнопізнавальної діяльності, педагогічної підтримки, розвиток виконавської рефлексії, самоаналізу тощо.

Проведене дослідження засвідчує необхідність подальшого розроблення означеної проблеми в напрямках: визначення ефективних шляхів забезпечення якості інструментально-виконавської підготовки майбутніх учителів музики 3 метою 
підвищення їх конкурентоспроможності на ринку праці. активізації мотиваційної сфери студентів до пізнавальної та виконавської діяльності, яка $є$ необхідною умовою подальшої продуктивної роботи з учнями; розробленні різних методик фахового навчання студентів за модульно-рейтинговим навчанням.

\section{Література}

1. Алексюк А. М. Експериментальне впровадження технології модульної організації навчання у вищій школі / А. М. Алексюк // Проблеми вищої школи: наук.метод. зб. / Ін-т системних досліджень освіти. - К., 1994. - Вип. 8. - С. 3-6. 2. Бондар В. І. Модульно-рейтингова технологія вивчення дисципліни (на матеріалі дидактики): [навч. посіб.] / В. І. Бондар. - К. : НПУ, 1999. - 48 с. З. Падалка Г. М. Педагогіка мистецтва (Теорія і методика викладання мистецьких дисциплін) - К. : Освіта України, 2008. - 274 с. 4. Педагогіка вищої школи: [підручник] // за ред. В. Г. Кременя, В. П. Андрущенка, В.І.Лугового. - К. : Педагогічна думка, 2009. 255 с. 5. Щолокова О. П. Основи професійної художньо-естетичної підготовки майбутнього вчителя: [монографія] / Ольга Пилипівна Щолокова. - К. : Укр. держ. пед. ун-т імені М. П. Драгоманова, 1996. - 172 с.

УДК $811.112 .2 ’ 27$

Ігор Горошкін

\section{МЕТОД ПРОЕКТІВ У ПРОФЕСІЙНІЙ ПІДГОТОВЦІ МАЙБУТНІХ ПЕРЕКЛАДАЧІВ}

Горошкін І. О. Метод проектів у професійній підготовці майбутніх перекладачів.

У статті визначено педагогічний потенціал методу проектів у професійній підготовці майбутніх перекладачів, проаналізовано особливості впровадження міждисциплінарних проектів, що значною мірою впливають на сформованість професійної компетентності студентів-майбутніх перекладачів, запропоновано тематику міждисциплінарних проектів, сценарії його реалізації.

Ключові слова: професійна підготовка, майбутній перекладач, метод проектів, міждисциплінарний проект.

Горошкин И. А. Метод проектов в профессиональной подготовке будущих переводчиков.

В статье определен педагогический потенциал метода проектов в профессиональной подготовке будущих переводчиков, проанализированы особенности реализации междисциплинарных проектов, которые в значительной степени влияют на сформированность профессиональной компетентности студентовбудущих переводчиков, предложено тематику междисциплинарных проектов, сценарии его реализации.

Ключевые слова: профессиональная подготовка, будущий переводчик, метод проектов, междисциплинарній проект.

Goroshkin I. A. Method of projects in professional training of future translators.

The article defined pedagogical potential of method of projects in the training of future translators, analyzed the features of interdisciplinary projects that have a significant impact on the formation of professional competence of students-future translators, suggested topics of interdisciplinary projects, scenarios for its implementation.

Key words: training, future translators, method of project, interdisciplinary project. 